antigua dominadora de América, no conoce bien la literatura ni las preocupaciones de las que fueron sus colonias. La intercalación del cuento es un acierto de interpretación y adaptación, es un juicio admirativo y una demostración de simpatía hacia el Dr. Atl, pero es también probablemente un desafío y una burla, una trampa sin disimulo, para la estrechez mental de ciertos críticos españoles ${ }^{12}$.

El Colegio de México.

Emma Susana Speratti Piñero

\title{
NOTA AL CABALLERO DE OLMEDO
}

En el acto segundo de El caballero de Olmedo, de Lope (vv. 211219), dice Tello:

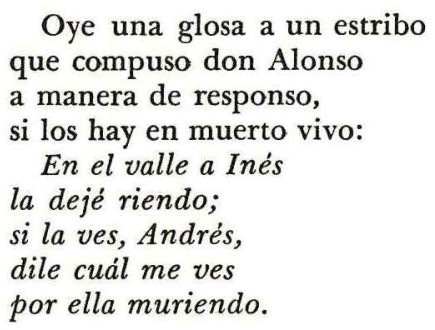

Pudiera pensarse -y yo así lo creí cuando preparé mi edición- que ese villancico era original del propio Lope, puesto que don Alonso está enamorado precisamente de Inés. Sin embargo, en la Flor de romances y glosas y canciones y villancicos..., impresa en Zaragoza en 1578 y reeditada por A. Rodríguez Moñino (Valencia, 1954), se halla, en las pp. 159-162, La glosa de Ynés, con una leve variante:

$$
\begin{aligned}
& \text { En el valle a Ynés, } \\
& \text { la topé riendo; } \\
& \text { si la ves, Andrés, } \\
& \text { dile quál me ves } \\
& \text { por ella muriendo. }
\end{aligned}
$$

Aquí, como en otros muchos casos, Lope se ha limitado a respetar la canción y a añadirle glosa nueva.

Zaragoza.

J. M. Blecua

12 De hecho, sólo la casualidad, y la circunstancia de estar estudiando los distintos elementos de Tirano Banderas, me han permitido hallar esta fuente parcial. En busca de textos que ilustraran el uso del vocabulario americanista en la Novela de Tierra Caliente, encontré la referencia bibliográfica correspondiente a las publicaciones del "Dr. Atl". El nombre me llamó la atención y me hizo pensar que era demasiada coincidencia la semejanza entre Dr. Atl y Doctor Atle. Pero sólo pude salir de dudas al llegar a México, pues me resultó imposible conseguir los libros en Buenos Aires. En cuanto a la actitud de Valle-Inclán al echar mano de un texto ajeno, creo haber dicho lo suficiente para que se entienda que estoy muy lejos de considerarla un plagio descarado. El mismo Dr. Atl, espíritu comprensivo y ágil, la ve como una interpretación de su propio tema. 